\title{
PENERAPAN STRATEGI REACT (RELATING, EXPERIENCING, APPLYING, COOPERATING AND TRANSFERRING) TERHADAP PENINGKATAN KEMAMPUAN PEMAHAMAN KONSEP MATEMATIS SISWA KELAS IV SD
}

\section{( THE APPLICATION OF THE REACT STRATEGY (RELATING, EXPERIENCING, APPLYING, COOPERATING AND TRANSFERRING) TO IMPROVING THE MATHEMATICAL CONCEPT ABILITY OF GRADE IV ELEMENTARY SCHOOL STUDENT)}

\author{
Melati Aini Sukma ${ }^{1}$, Indhira Asih Vivi Yandari ${ }^{2}$, Trian Pamungkas \\ Alamsyah ${ }^{3}$ \\ ${ }^{1}$ Universitas Sultan Ageng Tirtayasa, melatiains@gmail.com \\ ${ }^{2}$ Universitas Sultan Ageng Tirtayasa, indhira_1969@untirta.ac.id \\ ${ }^{3}$ Universitas Sultan Ageng Tirtayasa, trian@untirta.ac.id
}

\begin{abstract}
Abstrak
Penelitian ini dilatar belakangi bahwa pembelajaran matematika di sekolah belum memberikan ruang pada siswa untuk mengembangkan kemampuan pemahaman konsep matematis sehingga siswa tidak terlibat aktif dalam proses pembelajaran. Tujuan Penelitian ini untuk mengetahui penerapan strategi REACT dalam meningkatkan kemampuan pemahaman konsep matematis siswa. Metode penelitian ini merupakan penelitian kuasi eksperimen dengan desain nonequivalent control group design. Populasi yang diteliti adalah seluruh siswa kelas IV SDN Sempu 2 Kota Serang. Sedangkan sampelnya menggunakan purposive sampling dengan kelas IV B sebagai kelas eksperimen dan IV A sebagai kelas kontrol. Instrumen yang digunakan dalam penelitian ini adalah instrumen tes dan non-tes. Hasil penelitian menunjukkan bahwa terdapat perbedaan peningkatan kemampuan pemahaman konsep matematis siswa yang menggunakan strategi REACT dengan kemampuan pemahaman konsep matematis siswa yang menggunakan strategi Cooperative Learning dan peningkatan kemampuan pemahaman konsep matematis siswa yang menggunakan strategi REACT lebih baik daripada kemampuan pemahaman konsep matematis siswa yang menggunakan strategi Cooperative Learning.
\end{abstract}

Kata kunci: REACT, Kemampuan Pemahaman Konsep Matematis

\begin{abstract}
This research is in the background that learning mathematics in schools has not provided room for the students to develop the ability to understand mathematical concepst so that student are not actively involved in the learning process. The purpose of this research is to know the application of REACT strategy to improve the understanding skill of mathematical concepts of student. The research method is a quasi-experimental research with a nonequivalent control group design. The population studied were all grades IV students at SDN
\end{abstract}


Sempu 2 Kota Serang. The sample uses a purposive sampling with class IV B as an experimental class and IV A as the control class. The instruments used in this study are test and non test instruments. The result showed that there was a difference in the ability to understand the mathematical concepts of student using Cooperative Learning and improvement strategies. Ability to understand mathematical concepts of student using REACT strategy better than the ability to understand mathematical concepts of students using Cooperative Learning strategies

Keywords: REACT, Abiliy to Understand Mathematical Concepts.

\section{PENDAHULUAN}

Pendidikan merupakan unsur utama dalam pengembangan manusia, oleh karena itu pendidikan harus menciptakan perubahan yang lebih baik yaitu dengan cara menciptakan sistem pendidikan yang komprehensif dan fleksibel sehingga perlu adanya kurikulum sebagai pedoman penyelenggaraan kegiatan belajar mengajar. Sebagaimana tertera struktur kurikulum pendidikan dasar (dalam Peraturan Pemerintah Republik Indonesia Nomor 32 Tahun 2013) yaitu struktur kurikulum pendidikan dasar berisi muatan pembelajaran atau mata pelajaran yang dirancang untuk mengembangkan kompetensi spiritual keagamaan, sikap, sosial, pengetahuan, dan keterampilan. Secara umum tujuan penyelenggaraan pendidikan di Sekolah Dasar adalah untuk mengembangkan sikap dan kemampuan serta memberikan pengetahuan dan keterampilan dasar yang diperlukan untuk hidup dalam masyarakat serta mempersiapkan peserta didik mengikuti pendidikan menengah.

Pendidikan Sekolah Dasar merupakan lembaga yang penting dalam dunia pendidikan karena menyelenggarakan program pendidikan yang berkualitas dalam mencapai tujuan pendidikan nasional. Untuk mencapai tujuan nasional tersebut, pendidikan harus mampu menghasilkan sumber daya manusia yang berkualitas dan profesional. Guru merupakan komponen yang berpengaruh terhadap terciptanya proses dan hasil pendidikan yang berkualitas. Guru juga memiliki peranan penting dalam menciptakan suasana yang menyenangkan saat mengajarkan semua mata pelajaran di dalam kelas termasuk matematika. Matematika merupakan salah satu pelajaran yang wajib diajarkan di Sekolah Dasar. Matematika merupakan muatan pelajaran yang mengajarkan siswa untuk menjadi individu yang mandiri sehingga siswa dapat berpikir ilmiah dan logis, serta dapat memecahkan masalah yang dihadapinya dalam kehidupan sehari-hari. Materi yang terdapat di dalamnya pun dikaitkan dengan kegiatan sehari-hari, seperti menghitung, menjumlah, mengurang, dan membagi. Sehingga pembelajaran matematika haruslah menyenangkan dan menarik agar menciptakan suasana belajar yang aktif dan tidak membosankan.

Pelajaran matematika bertujuan untuk mempersiapkan siswa agar dapat menggunakan matematika dan pola pikir matematika dalam kehidupan sehari-hari dan dalam mempelajari ilmu pengetahuan (Umbara, 2017 : 13 ). Kegiatan proses pembelajaran yang baik, guru perlu mendorong siswa untuk mengembangkan kemampuan berpikir. Siswa diarahkan untuk memahami informasi yang diingatnya lalu menghubungkannya dengan kehidupan sehari-hari. Namun, pada 
kenyataanya pembelajaran Matematika yang diadakan di sekolah belum berjalan secara optimal. Pembelajaran Matematika yang seharusnya belajar menalar, berubah menjadi pelajaran menghafal sehingga pemahaman konsep tidak dipahami siswa sepenuhnya sehingga siswa tidak terlibat aktif dalam pembelajaran dan berimplikasi terhadap hasil belajar.

Pembelajaran matematika yang dilakukan dengan cara kurang tepat akan berakibat pada kesalahan konsep pada siswa. Mata pelajaran matematika merupakan pelajaran yang menekankan pada konsep artinya dalam mempelajari matematika siswa harus memahami konsep matematika terlebih dahulu agar dapat menyelesaikan soal-soal dan mampu mengaplikasikan pembelajaran tersebut dalam dunia nyata dan mampu mengembangkan kemampuan lain yang menjadi tujuan dari pembelajaran matematika (Murizal, $2012: 20$ ).

Menurut Dahar (Hutagalung, 2017:70) menyatakan bahwa jika diibaratkan, konsep-konsep merupakan batu-batu pembangunan dalam berpikir. Siswa akan mengalami kesulitan untuk menuju ke proses pembelajaran yang lebih tinggi jika belum memahami konsep. Oleh karena itu, kemampuan pemahaman konsep matematis merupakan tujuan penting dalam pembelajaran matematika. Kesalahan konsep pada siswa tersebut bisa di timbulkan karena siswa hanya mendengarkan saja penjelasan dari guru tanpa ikut terlibat langsung dalam proses pembelajaran. Selain itu, kurangnya kesadaran guru untuk menanamkan pemahaman matematis kepada siswa . Kurangnya pemahaman matematis yang dimiliki guru salah mengartikan tentang suatu konsep. Dengan menanamkan pemahaman matematis guru akan ikut terlibat aktif sehingga pembelajaran matematika di dalam kelas tidak lagi terasa membosankan dan menakutkan bagi siswa.

Kurangnya pemahaman konsep matematis sering ditemukan pada materi bangun datar. Masih banyak siswa yang hanya sekedar tahu rumus dari bangun datar dengan cara menghafal tanpa mengetahui asal rumus tersebut sehingga guru merasa kesulitan dalam memahami konsep keliling dan luas pada suatu bentuk bangun datar tertentu. Mereka beranggapan bahwa keliling dan luas adalah sama sehingga merasa bingung dalam memahami keduanya dan jika di hadapkan pada dua buah bentuk yang memiliki luas sama, maka siswa beranggapan bahwa kelilingnya adalah sama.

Pemahaman terhadap konsep matematis merupakan salah satu dari tujuan pembelajaran matematika disekolah yang sangat mendasar dalam pembelajaran matematika agar belajar menjadi lebih bermakna. Untuk menanamkan pemahaman matematis siswa adalah menerapkan pembelajaran yang mengaitkan materi pembelajaran dengan kehidupan sehari-hari. Model pembelajaran yang cocok dengan tujuan tersebut adalah pembelajaran kontekstual. Pembelajaran kontekstual merupakan pembelajaran yang mengaitkan materi pembelajaran dengan konteks kehidupan sehari-hari siswa yang bertujuan untuk memotivasi siswa dalam memahami makna dari materi yang dipelajarinya dengan kehidupan sehari-hari siswa. Strategi REACT (Relating, Experiencing, Applying, Cooperating, and Transferring) merupakan salah satu strategi yang berlandaskan pembelajaran kontekstual.

Berdasarkan hal tersebut, strategi REACT (Relating, Experiencing, Applying, Cooperating, and Transferring) digunakan untuk mengetahui apakah peningkatan kemampuan pemahaman konsep matematis yang menggunakan 
strategi REACT lebih baik daripada peningkatan kemampuan konsep matematis yang menggunakan strategi Cooperative Learning. Melihat begitu pentingnya pemahaman konsep dalam pembelajaran matematika pelaksanaan strategi REACT dirasa tepat dalam mendukung proses pembelajaran Matematika khususnya untuk mendukung kemampuan terhadap konsep pemahaman matematis siswa. Karakteristik pembelajaran kontekstual meliputi pembelajaran yang menerapkan konsep keterkaitan (Relating), konsep pengalaman langsung (Experiencing), konsep aplikasi (Applying), konsep kerja sama (Cooperating), dan konsep mentransfer (Transferring) kelima karakteristik ini dapat membantu siswa untuk memahami konsep materi pelajaran khususnya Matematika.

\section{KAJIAN TEORI \\ Strategi REACT}

Strategi REACT pertama kali dikembangkan di Amerika Serikat. Strategi ini merupakan pengembangan dari Contextual Teaching and Learning (CTL). Siregar dan Nana (2010: 117) mengungkapkan bahwa CTL adalah konsep belajar yang ditunjukan oleh guru dengan menghadirkan dunia nyata ke dalam kelas dan mendorong siswa membuat hubungan antara pengetahuan yang dimiliki dengan pengetahuan baru maupun penerapan dalam kehidupan sehari-hari.

Menurut Crawford (2001: 3) strategi REACT terdiri dari lima komponen yaitu relating (mengaitkan), experiencing (mengalami), applying (menerapkan), cooperating (bekerjasama), dan transferring (mentransfer). Kelima komponen tersebut merupakan satu kesatuan yang diperlukan untuk menciptakan proses pembelajaran

Strategi REACT merupakan strategi pembelajaran kontekstual yang melibatkan lima aspek yaitu menghubungkan materi ajar dengan pengalaman hidup (Relating), belajar dengan konteks eksplorasi atau penemuan konsep (Experiencing), penerapan konsep (Applying), memberikan kesempatan kepada siswa belajar melalui bekerja sama dan berbagi (Cooperating) dan memberikan kesempatan kepada siswa melakukan transfer pengetahuan ke dalam konteks yang baru (Transferring). Hal tersebut didukung oleh Sounders (Komalasari, 2010) menjelaskan bahwa REACT merupakan fokusan dari pembelajaran kontekstual. Pembelajaran kontekstual adalah konsep belajar yang membantu guru mengaitkan materi yang diajarkan dengan situasi dunia nyata siswa dan/atau mendorong siswa membuat hubungan antara pengetahuan yang dimilikinya dengan penerapannya dalam kehidupan sehari-hari. Strategi REACT merupakan salah satu strategi pembelajaran yang dapat membantu guru untuk menanamkan konsep pada siswa, sehingga siswa tidak sekedar menghafal rumus, akan tetapi siswa dapat menemukan sendiri, bekerjasama, dapat menerapkan dalam kehidupan dan dapat mentransfer dalam konteks baru, sekaligus belajar untuk selalu mengaitkan dengan konteks.

\section{Kemampuan Pemahaman Konsep Matematis}

Pemahaman konsep merupakan suatu aspek yang sangat penting dalam pembelajaran, karena dengan memahami konsep siswa dapat mengembangkan kemampuannya dalam setiap materi pelajaran. Pemahaman konsep terdiri dari dua kata yaitu pemahaman dan konsep. Menurut Thobroni (2015:21) teori mengenai pemahaman yang dikemukakan pada Taksonomi Bloom yaitu comprehension 
(C2) diartikan sebagai pemahaman, menjelaskan, meringkas, contoh. Dalam hal ini pemahaman berada pada salah satu aspek kognitif kedua yaitu C2 sebagai kemampuan yang digunakan untuk memberikan makna ide atau konsep bahkan sebagai penegasan terhadap makna atau konsep tersebut. Makna yang dijelaskan dapat berupa tulisan maupun lisan, serta dalam pemahaman akan dapat menyebutkan suatu contoh.

Menurut Carrol (Trianto, 2010:158) konsep adalah suatu abstraksi dari serangkaian pengalaman yang didefinisikan sebagai suatu kelompok objek atau kejadian. Banyaknya pengalaman yang dimiliki dan terlihat atau terpikir kurang tampak pada peristiwa nyata dapat ditarik menjadi suatu istilah sebagai definisi. Begitu juga objek yang terdapat dalam alam baik wujud maupun tidak menjadi istilah yang dikonsepsikan.

Menurut Benyamin S. Blom ( Daryanto, 2012 : 106) kemampuan pemahaman (comprehension) dibagi menjadi tiga antara lain : pertama, translation yaitu menerjemahkan bukan hanya pada arti bahasa melainkan dapat juga dari konsepsi abstrak menjadi suatu model yaitu model simbolik. Kedua, interpretation yaitu kemampuan untuk mengenal dan memahami, misal menafsirkan tabel, diagram, grafik,dan gambar lain. Ketiga, extrapolation yaitu lebih dari menerjemahkan dan menafsirkan. Akan tetapi memperhitungkan, memperkirakan, menduga, menyimpulkan, meramalkan, membedakan, menentukan, mengisi, dan menarik kesimpulan.

KBBI mengatakan pemahaman berarti proses, perbuatan, cara memahami atau memahamkan (Mike, 2012 : 68). Sedangkan konsep merupakan buah pemikiran seseorang atau sekelompok orang yang dinyatakan dalam definisi sehingga melahirkan produk pengethuan meliputi prinsip, hokum dan teori. Tujuan mempelajarai konsep adalah agar siswa paham, dapat menunjukkan ciriciri, unsur, membedakan, membandingkan, menggeneralisasi, dan sebagainya.

Menurut Gusniwati (2015: 30) pemahaman konsep adalah suatu kemampuan menemukan ide abstrak dalam matematika untuk mengklasifikasikan objek-objek yang biasanya dinyatakan dalam suatu istilah kemudian dituangkan kedalam contoh dan bukan contoh, sehingga seseorang dapat memahami suatu konsep dengan jelas.

Menurut Rianti dan Nulhakim (2017: 66) kemampuan pemahaman konsep merupakan tingkat kemampuan yang mengharapkan siswa tidak hanya mengetahui yang sifatnya mengingat saja, tetapi mampu menguasai atau memahami konsep.

\section{METODE PENELITIAN}

Metode penelitian yang digunakan dalam penelitian ini adalah metode kuasi eksperimen. Kuasi eksperimen design, digunakan karena pada kenyataannya sulit mendapatkan kelompok kontrol yang digunakan untuk penelitian (Sugiyono, 2013 : 116). Dalam penelitian ini peneliti menggunakan dua kelompok yang diberi perlakuan yang berbeda. Kelompok yang pertama adalah kelompok yang diberi perlakuan menggunakan strategi REACT (Relating, Experiencing, Applying, Cooperating, and Transferring ) sebagai kelas eksperimen, sedangkan kelompok yang menggunakan strategi Cooperative Learning sebagai kelas kontrol. Desain penelitian yang digunakan dalam penelitian ini adalah nonequivalent control group design (Sugiyono, 2015 : 116). Desain ini hampir 
sama dengan pretest-posttest control group design, hanya pada desain ini kelompok eksperimen maupun kelompok kontrol tidak dipilih secara random atau acak.

Populasi dalam penelitian ini adalah seluruh siswa kelas IV SD Negeri Sempu 2 tahun ajaran 2020/2021 dengan jumlah siswa yaitu 42 siswa. Pengambilan sampel dalam penelitian ini adalah Nonprobability Sampling. Nonprobability sampling yang digunakan dalam penelitian ini adalah teknik purposive sampling yaitu yaitu kelas IV B menjadi sampel kelas eksperimen dan kelas IV A menjadi sampel kelas kontrol. Pengumpulan data dalam penelitian dilakukan dengan metode tes menggunakan tes uraian sebanyak 10 soal yang telah dipilih sesuai kriteria analisis uji instrumen, meliputi analisis validitas, reliabilitas, taraf kesukaran, dan daya pembeda soal. Tes dilakukan sebanyak dua kali yakni tes awal (pretest) dan tes akhir (posttest). Pada data hasil pretest dan posttest dilakukan uji normalitas (Chi Kuadrat), uji homogenitas (Uji F), hipotesis dan gain.

\section{HASIL DAN PEMBAHASAN}

Hasil penelitian berupa deskripsi data pretest dan posttest. Berikut soal pretest dan posttest yang digunakan dalam penelitian.
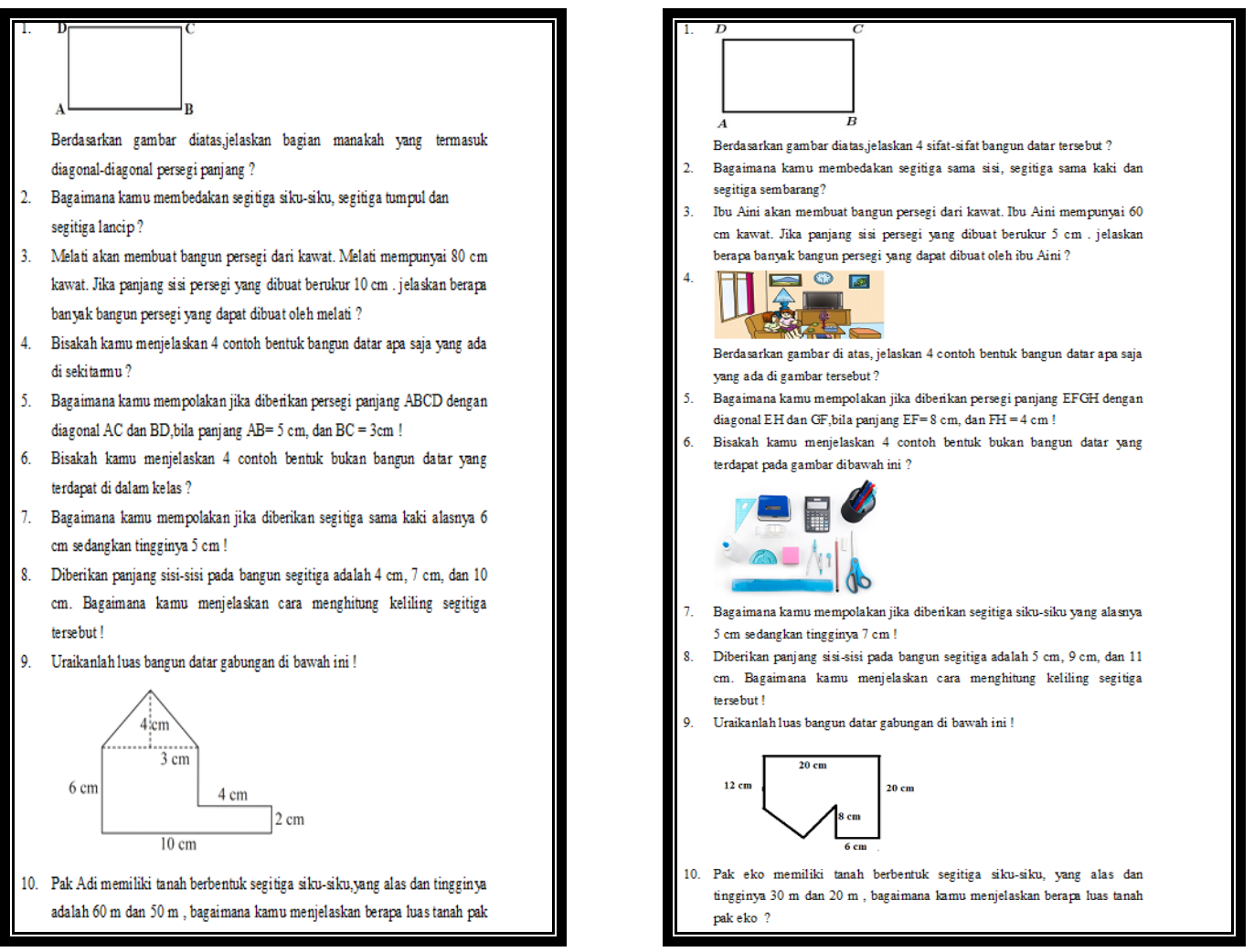

\section{Gambar 1. Soal Pretest dan Posttest}

Hasil pretest kelas eksperimen dan kontrol pada materi bangun datar dapat dilihat dalam tabel 1 berikut.

Tabel 1. Hasil Pretest Kelas Eksperimen dan Kelas Kontrol 


\begin{tabular}{ccc}
\hline Kelas & Eksperimen & Kontrol \\
Tes & Pretest & Pretest \\
\hline $\bar{x}$ ( Rata- Rata) & 25,92 & 31 \\
$\%$ (Interpretasi $)$ & $25,9 \%$ & $31 \%$ \\
$\mathrm{~S}$ (Simpangan Baku) & 8,880 & 10,21 \\
$S^{2}$ (Varians) & 78,88 & 104,3 \\
Hasil Uji Normalitas & Normal & Normal \\
Hasil Uji Homogenitas & \multicolumn{2}{c}{ Homogen } \\
Uji t-test Polled Varians Dua & $\mathrm{t}_{\text {hitung }} \leq \mathrm{t}_{\text {tabel, }} H_{0}$ diterima dan $H_{\alpha}$ ditolak \\
Pihak
\end{tabular}

Berdasarkan data pada Tabel 1 , terlihat nilai rata-rata kelas eksperimen $(25,92)$ lebih rendah dibandingkan kelas kontrol (31). Selain itu kedua kelas homogen, hal ini berarti kedua kelas memiliki kemampuan awal yang sama dan hasil uji hipotesis menunjukkan bahwa $t_{\text {hitung }} \leq t_{\text {tabel yaitu 1,67 }} \leq 2,021$ tidak terdapat perbedaan kemampuan pemahaman konsep matematis yang menggunakan strategi REACT (Relating, Experiencing, Applying, Cooperating, and Transferring) dengan kemampuan pemahaman konsep matematis yang menggunakan strategi Cooperative Learning pada pretest.

Hasil posttest kelas eksperimen dan kelas kontrol pada materi bangun datar dapat dilihat dalam Tabel 2 berikut.

Tabel 2. Hasil Posttest Kelas Eksperimen dan Kelas Kontrol

\begin{tabular}{ccc}
\hline Kelas & Eksperimen & Kontrol \\
Tes & Posttest & Posttest \\
\hline $\bar{x}$ ( Rata- Rata) & 65 & 54,43 \\
$\%$ (Interpretasi $)$ & $65 \%$ & $54,4 \%$ \\
$\mathrm{~S}$ (Simpangan Baku) & 13,75 & 13,09 \\
$S^{2}$ (Varians) & 189 & 171,26 \\
Hasil Uji Normalitas & Normal & Normal \\
Uji Homogenitas & \multicolumn{2}{c}{ Homogen } \\
Uji t-test Polled Varians Dua & \multicolumn{2}{c}{$\mathrm{t}_{\text {hitung }}>\mathrm{t}_{\text {tabel }}, H_{0}$ ditolak dan $H_{\alpha}$} \\
Pihak & \multicolumn{2}{c}{ diterima } \\
Uji t-test Polled Varians Satu & \multicolumn{2}{c}{ Pihak }
\end{tabular}

Hasil Posttest pada Tabel 2 diatas menunjukkan bahwa nilai rata-rata kelas eksperimen (65) lebih tinggi dari kelas kontrol $(54,43)$. Berdasarkan pengujian hipotesis terhadap data posttest menunjukan bahwa terdapat perbedaan kemampuan pemahaman konsep matematis antara kelas eksperimen dan kontrol. Hal ini dibuktikan dengan $t_{\text {hitung }}>t_{\text {tabel }}$ atau 2,491 $>2,021$. Kemudian diketahui kemampuan pemahaman konsep matematis siswa kelas eksperimen lebih baik daripada kemampuan pemahaman konsep matematis siswa kelas kontrol. Hal ini dibuktikan dengan $t_{\text {hitung }}>t_{\text {tabel }}$ atau 2,491 $>1,684$. Hal ini menunjukkan bahwa kemampuan pemahaman konsep matematis siswa terdapat perbedaan dan lebih 
baik daripada kemampuan pemahaman konsep matematis siswa kelas kontrol. Dalam pembelajaran menggunakan strategi REACT (Relating, Experiencing, Applying, Cooperating, and Transferring) siswa diberikan permasalahan kontekstual sehingga pembelajaran berkaitan dengan dunia nyatanya, hal tersebut yang membuat kemampuan pemahaman konsep dikelas eksperimen lebih baik daripada kelas kontrol.

Hasil data gain kemampuan pemahaman konsep matematis siswa pada materi bangun datar dapat dilihat dalam Tabel 3 berikut.

Tabel 3. Hasil Gain Kemampuan Pemahaman Konsep Matematis Siswa

\begin{tabular}{ccc}
\hline Kelas & Eksperimen & Kontrol \\
Tes & Postest & Postest \\
\hline $\bar{x}$ ( Rata- Rata) & 0,5064 & 0,3179 \\
$\%$ (Interpretasi $)$ & $51 \%$ & $32 \%$ \\
$\mathrm{~S}$ (Simpangan Baku) & 0,1844 & 0,2265 \\
$S^{2}$ (Varians) & 0,034 & 0,051 \\
Hasil Uji Normalitas & Normal & Normal \\
Uji Homogenitas & & \\
Uji t-test Polled & & \\
Varians Dua Pihak & $\mathrm{t}_{\text {hitung }}>\mathrm{t}_{\text {tabel }}, H_{0}$ ditolak dan $H_{\alpha}$ diterima \\
Uji t-test Polled & & \\
Varians Satu Pihak & & \\
\hline
\end{tabular}

Untuk data gain pada Tabel 3 menunjukkan bahwa nilai rata-rata gain kelas eksperimen yang lebih tinggi $(0,5064)$ dari nilai rata-rata gain kelas kontrol $(0,3179)$. Berdasarkan pengujian hipotesis uji-t data gain diketahui terdapat perbedaan peningkatan kemampuan pemahaman konsep matematis antara kelas eksperimen dan kelas kontrol. Hal ini dibuktikan dengan $t_{\text {hitung }}$ lebih besar dari $\mathrm{t}_{\text {tabel }}$ yaitu 2,891>2,021. Kemudian diketahui bahwa peningkatan kemampuan pemahaman konsep matematis kelas eksperimen lebih baik daripada kemampuan pemahaman konsep matematis kelas kontrol. Hal ini dapat dibuktikan dengan $t_{\text {hitung }}$ lebih besar dari $t_{\text {tabel }}$ yaitu 2,891 > 1,684. Dengan demikian kemampuan pemahaman konsep matematis siswa terdapat perbedaan peningkatan antara kelas eksperimen dan kelas kontrol, dan kelas eksperimen peningkatannya lebih baik daripada kelas kontrol.

Pada pelaksanaan, peneliti terlebih dahulu memberikan pretest dengan tujuan untuk mengetahui pengetahuan awal peserta didik terhadap materi bangun datar. Pretest ini diberikan pada hari pertama penelitian sebelum diberikan perlakuan dan nilai rata-rata pada kelas eksperimen yaitu 25,92 dan kelas kontrol yaitu 31 hal ini menunjukkan bahwa kedua kelas tersebut memiliki kemampuan awal yang setara hal ini sesuai menurut Effendy (2016: 83) yang menyatakan hasil dari pretest akan membantu mengintegrasikan dari pemahaman siswa sebelumnya dengan informasi yang baru sehingga bahan atau materi yang akan diajarkan dapat disesuaikan dengan kemampuan siswa itu sendiri, atau terjadinya penyesuaian pemahaman siswa kedalam materi baru jika materi belum dikuasai sedikitpun oleh siswa. Dilihat dari analisis data Pretest dengan menggunakan uji-t dua pihak 
menunjukkan bahwa $t_{\text {hitung }} \leq \mathrm{t}_{\text {tabel }}$ atau 1,67 $\leq 2,021$ maka tidak terdapat perbedaan antara kemampuan pemahaman konsep matematis siswa kelas eksperimen dengan kemampuan pemahaman konsep matematis siswa kelas kontrol sebelum diberikan kegiatan pembelajaran dengan menggunakan strategi pembelajaran.

Setelah diberikan pretest dilanjutkan dengan pemberian materi baik pada kelas eksperimen maupun kelas kontrol. Pada pembelajaran dikelas eksperimen digunakan model pembelajaran REACT. Pembelajaran diawali dengan ucapan salam, berdo'a dan mengecek kehadiran siswa serta apersepsi dan menyampaikan tujuan. Dalam pembelajaran yang menggunakan strategi REACT peserta didik dihubungkan dengan benda-benda bangun datar yang ada dilingkungan sekitar atau di dalam kelas, sehingga peserta didik lebih paham apa yang dimaksud dengan keliling dan luas serta menghitung keliling benda bangun datar yang mereka punya menggunakan penggaris. Dalam hal ini peserta didik terlihat lebih antusias daripada langsung menghitung keliling yang sudah diketahui.

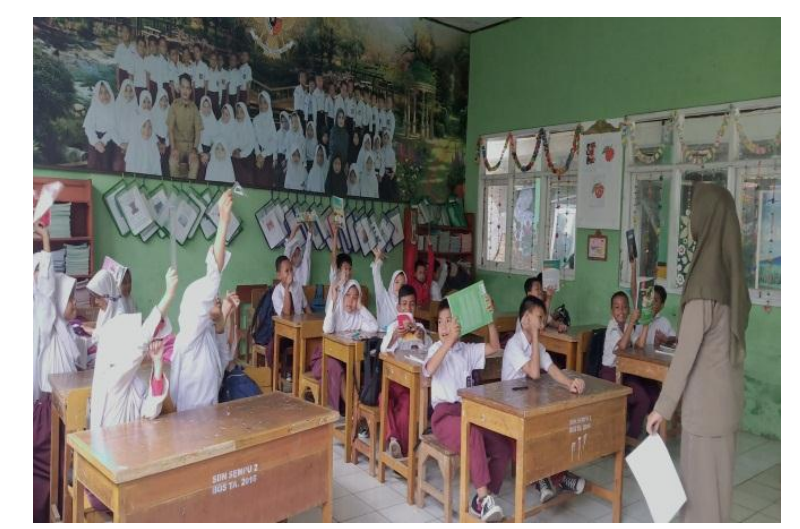

Gambar 2. Aktivitas Siswa Pada Tahap Relating

Selanjutnya siswa dilibatkan dalam aktivitas menemukan rumus dengan menggunakan media kertas yang gunting menjadi beberapa bagian kemudian siswa diarahkan untuk menemukan rumus dengan petunjuk-petunjuk yang ada. Dalam hal ini peserta didik sangat cermat dalam melakukan kegiatan tersebut karena membutuhkan konsentrasi dalam mengerjakannya.

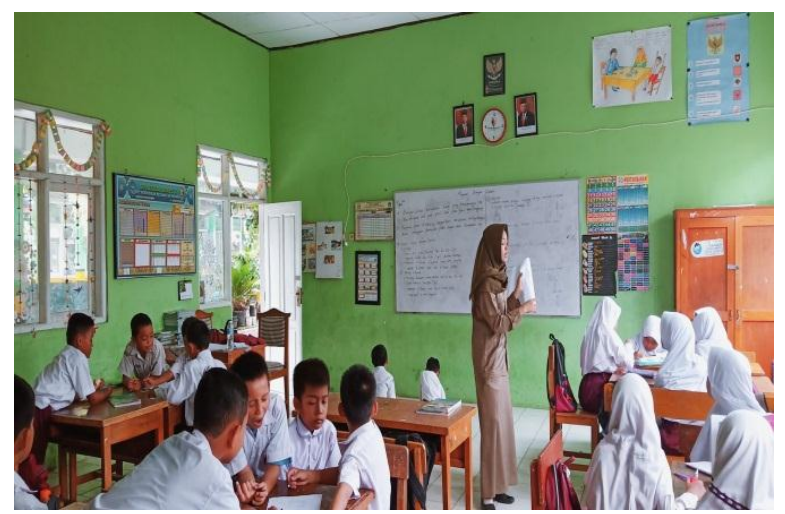

Gambar 3. Aktivitas Siswa Pada Tahap Experiencing 
Setelah menemukan rumus, peserta didik diminta untuk mengimplementasikan rumus tersebut ke dalam lembar kerja yang telah disediakan oleh pendidik.

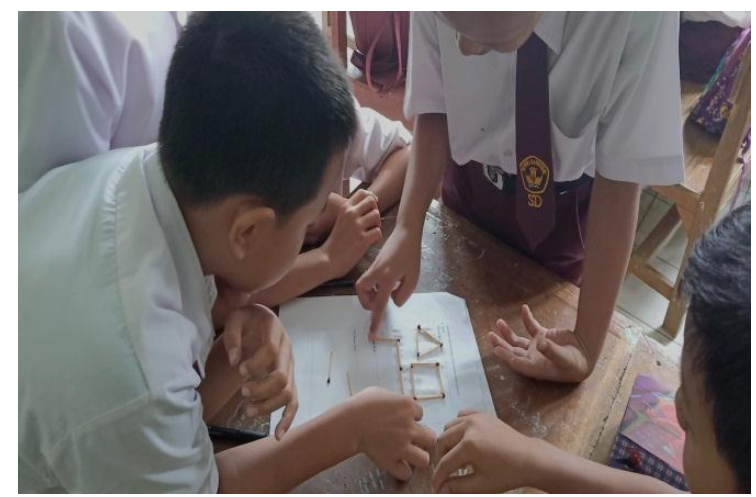

Gambar 4. Aktivitas Siswa Pada Tahap Applying

Pemberian LKPD sendiri bertujuan agar peserta didik memahami bahwa materi yang sedang dipelajari ada pemanfaatannya dalam kehidupan nyata serta peserta didik bekerja sama dalam kegiatan pembelajaran. Tahap ini juga mendukung dalam kegiatan relating, experiencing, dan applying agar kondisi kelas kondusif dan efektif dalam belajar.

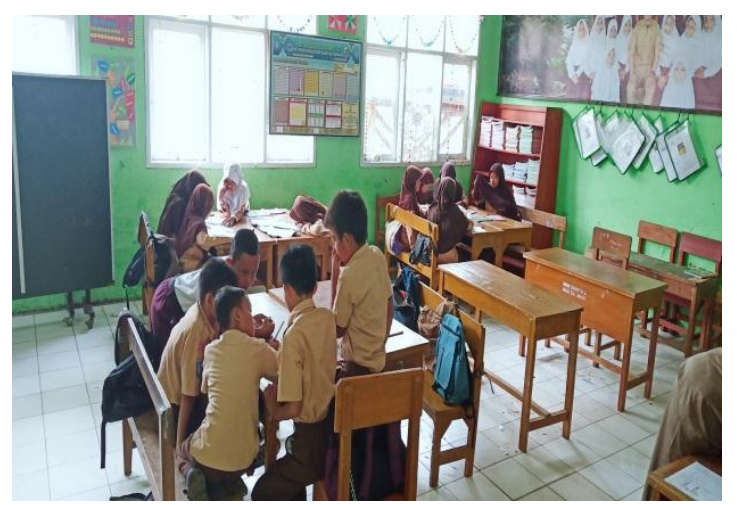

Gambar 5. Aktivitas Siswa Pada Tahap Cooperating

Diakhir tahap ini peserta didik diminta untuk mengkomunikasikan hasil kerjanya didepan kelas. Hal ini bertujuan agar siswa lebih percaya diri dalam menyampaikan pendapat dan menerima pendapat dari peserta didik lainnya.

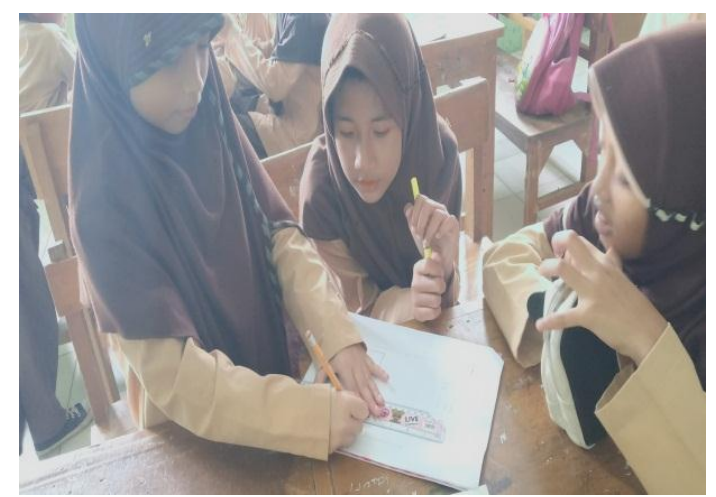

Gambar 5. Aktivitas Siswa Pada Tahap Transferring 
Selanjutnya peserta didik di berikan soal-soal latihan yang lebih bervariasi dan menantang kreativitas peserta didik dalam mengerjakannya dan bertujuan untuk mengetahui sejauh mana pencapaian peserta didik dalam memahami materi pada hari itu. Hal ini sesuai dengan teori menurut Sanjaya (2010:23) dalam proses pembelajaran yang menerapkan strategi REACT, guru berperan sebagai fasilitator yaitu memberikan pelayanan untuk memudahkan siswa dalam kegiatan proses pembelajaran. Sedangkan pembelajaran yang menggunakan strategi Cooperative Learning materi yang diberikan sama dengan materi yang diberikan pada pembelajaran strategi REACT yaitu materi bangun datar. Proses pembelajaran dilaksanakan sebanyak 4 kali pertemuan. Dalam proses pembelajaran peserta didik lebih didominasi dengan kegiatan bekerja sama dan mentransfer pengetehuan yang dimiliki pendidik kepada peserta didik, peserta didik dengan peserta didik lainnya. Posttest diberikan setelah proses pembelajaran dimasingmasing kelas untuk mengetahui pencapaian akhir test kemampuan pemahaman konsep pada mata pelajaran Matematika. Kelas ekseprimen diberi perlakuan strategi pembelajaran REACT dan kelas kontrol diberi perlakuan strategi Cooperative Learning. Hasil tes kemampuan pemahaman konsep kelas eksperimen memperoleh nilai rata-rata 65 sedangkan kelas kontrol memperoleh nilai rata-rata 54,43. Dilihat dari analisis data posttest dengan menggunakan uji-t dua pihak menunjukkan bahwa bahwa $t_{\text {hitung }}>t_{\text {tabel }}$ atau 2,491 $>2,021$ maka terdapat perbedaan antara kemampuan pemahaman konsep matematis siswa kelas eksperimen dengan kemampuan pemahaman konsep matematis siswa kelas kontrol setelah diberikan kegiatan pembelajaran dengan menggunakan strategi pembelajaran.

Berdasarkan hasil penelitian menunjukkan bahwa peningkatan kemampuan pemahaman konsep yang menggunakan strategi REACT (Relating, Experiencing, Applying, Cooperating, and Transferring) lebih baik daripada kemampuan pemahaman konsep yang menggunakan strategi Cooperative Learning hal ini dikarenakan dalam pembelajaran peserta didik bukan hanya menerima informasi yang disampaikan oleh guru,tetapi mengeksplorasi pengetahuannya sendiri dengan kegiatan-kegiatan seperti melakukan aktivitas dan menemukan rumusnya sendiri juga dihadapkan pada soal-soal aplikasi dan transfer, sehingga siswa akan mengetahui secara langsung pentingnya materi dan kegunaannya dalam kehidupan sehari-hari. Hal ini sesuai dengan teori menurut Gulo (2010:31) mengenai kelebihan strategi REACT yaitu memperdalam pemahaman siswa dengan cara mengerjakan LKPD sehingga bisa mengkaitkan dan mengalami sendiri prosesnya, mengembangkan sikap menghargai diri siswa dan orang lain, mengembangkan sikap kebersamaan dan rasa saling memiliki dengan bekerja sama akan melahirkan komunikasi sesama siswa dalam aktivitas dan tanggung jawab, mengembangkan keterampilan untuk masa depan, memudahkan siswa mengetahui kegunaaan materi dalam kehidupan sehari-hari, membuat belajar secara inklusif dengan dihadapkan pada pengaplikasian dan pentransferan konsep yang juga merupakan aktivitas pemecahan masalah.

Berdasarkan penelitian aktivitas peserta didik pada kelas yang menggunakan strategi REACT atau kelas eksperimen dalam pembelajarannya rata-rata persentase terendah aktivitas peserta didik dari kelas eksperimen adalah pada saat pertemuan pertama karena pada pertemuan tersebut peserta didik tidak terlihat aktif bertanya untuk mengemukakan kesulitan yang dihadapi kepada 
pendidik akan tetapi secara perlahan pada pertemuan kedua peserta didik terlihat semangat dalam mengerjakan soal dan mengumpulkannya tepat waktu dan cepat merespon pertanyaan-pertanyaan yang berikan. Dalam mengerjakan soal terlihat peserta didik sudah mulai menjawab pertanyaan dengan jawaban yang bervariasi serta sangat antusias dalam mengemukakan pendapat didepan kelas.Pada saat pertemuan ketiga, peserta didik terlihat mulai aktif bertanya dan menyampaikan kesulitan-kesulitan yang didapati begitupun pada pertemuan ke empat sehingga hasil rata-rata aktivitas peserta didik setiap pertemuan selanjutnya meningkat. Menurut Widodo (2013 : 34) Aktivitas siswa sangat mendukung pembelajaran karena merubah tingkah laku melalui perbuatan adalah prinsip belajar. Ada atau tidaknya belajar dicerminkan dari ada atau tidaknya aktivitas. Tanpa ada aktivitas, belajar tidak mungkin terjadi. Sehingga dalam interaksi belajar-mengajar aktivitas merupakan prinsip yang penting

\section{SIMPULAN DAN SARAN}

Berdasarkan hasil penelitian dan analisis data serta pengujian hipotesis dalam penelitian ini, maka dapat disimpulkan bahwa peningkatan kemampuan pemahaman konsep matematika pada siswa yang menggunakan strategi REACT (Relating, Experiencing, Applying, Cooperating, and Transferring) menunjukkan bahwa peningkatannya lebih baik daripada kemampuan pemahaman konsep siswa yang menggunakan strategi Cooperative Learning dan aktivitas siswa pada kelas eksperimen yang menggunakan strategi REACT (Relating, Experiencing, Applying, Cooperating, and Transferring) memberikan hasil yang baik terhadap proses pembelajaran kemampuan pemahaman konsep matematis siswa

\section{DAFTAR RUJUKAN}

Crawford, L.M. (2001). Teaching Contextually: Research, Rationale, and Techniques for Improving Student 'Motivation and Achievement in Mathematics and science. Texas: CCI Publishing, INC.

Daryanto. (2012). Evaluasi Pendidikan. Jakarta: PT Rineka Cipta.

Effeny,Ilham. (2016). Pengaruh Pemberian Pre-Test dan Post-Test terhadap Hasil Belajar Mata Diklat Hdw.Dev.100.2.A pada Siswa SMK Negeri 2 Lubuk Basung. Jurnal Ilmiah Pendidikan Teknik Elektro, 1(2) : 81-88.

Gulo, A. (2010). Penerapan Strategi REACT Untuk Meningkatkan Pemahaman Siswa Pada Materi Fungsi di Kelas XI SMA Negeri 1 Kutapanjang. Medan: Tesis.

Gusniawati, M. (2015). Pengaruh Kecerdasan Emosional dan Minat Belajar terhadap Penguasaan Konsep Matematika Siswa SMAN di Kecamatan Kebon Jeruk. Jurnal Formatif ,5(1), 26-41

Hutagalung, R. (2017). Peningkatan Kemampuan Pemahaman Konsep Matematis Siswa Melalui Pembelajaran Guided Discovery Berbasis Budaya Toba Di SMP Negeri Itukka. Journal Of Mathematics Education And Science, 2(2), 70-77

Kemendikbud. (2013). Kerangka Dasar dan Struktur Kurikulum 2013. Jakarta: Kemendikbud.

Komalasari, K. (2010). Pembelajaran Kontekstual Konsep dan Aplikasi. Bandung: PT. Refika Aditama. 
Mike, P. (2012). Pemahaman Konsep Matematika Pada Materi Turunan Melalui Pembelajaran Teknik Probing. Jurnal UNP.

Murizal, A., \& dkk. (2012). Pemahaman Konsep Matematis dan Model Pembelajaran Quantum Teaching. Jurnal Pendidikan Matematika, 1(1)

Rianti,L.,\& Nulhakim, L. (2017). Pengaruh Model Student Facilitator and Explaining (SFAE) terhadap Pemahaman Konsep Siswa Kelas IV pada Mata Pelajaran IPA. JPSD, 3(1), 64-73.

Sanjaya,W. (2010). Strategi Pembelajaran Berorientasi Standar Proses Pendidikan. Jakarta: Kencana.

Siregar, E.,\& Nana,H. (2010). Teori Belajar dan Pembelajaran. Bogor: Ghalia Indonesia.

Sugiyono. (2013). Metode Penelitian Pendidikan (Pendekatan Kuantitatif, Kualitatif, dan $R \& D)$ ). Bandung: Alfabeta.

Sugiyono. (2015). Metode Penelitian Pendidikan. Bandung: ALPABETA.

Thobroni. (2015) . Belajar dan Pembelajaran Teori dan Praktik. Yogyakarta: ARRUZZ MEDIA

Trianto. (2010). Mendesain Model Pembelajaran Inovatif-Progresif. Jakarta: Kencana.

Umbara,U. (2017). Psikologi Pembelajaran Matematika. Yogyakarta: Deepublish.

Widodo,L. 2013. Peningkatan Aktivitas Belajar dan Hasil Belajar Siswa dengan Metode Problem Based Learning pada Siswa Kelas VII MTs Negeri Donomulyo Kulon Progo Tahun Pelajaran 2012/2013. Jurnal Fisika Indonesia, 49 (XVII) : 32-35. 